University of Louisville

ThinkIR: The University of Louisville's Institutional Repository

Faculty Scholarship

8-2007

\title{
Whiteness in Du Bois's The Souls of Black Folk
}

David S. Owen

University of Louisville, david.owen@louisville.edu

Follow this and additional works at: https://ir.library.louisville.edu/faculty

Part of the English Language and Literature Commons, Philosophy Commons, and the Race, Ethnicity and Post-Colonial Studies Commons

Original Publication Information

Owen, D.S. "Whiteness in Du Bois's The Souls of Black Folk." 2007. Philosophia Africana 10(2): 107-126.

ThinkIR Citation

Owen, David S., "Whiteness in Du Bois's The Souls of Black Folk" (2007). Faculty Scholarship. 423.

https://ir.library.louisville.edu/faculty/423

This Article is brought to you for free and open access by ThinkIR: The University of Louisville's Institutional Repository. It has been accepted for inclusion in Faculty Scholarship by an authorized administrator of ThinkIR: The University of Louisville's Institutional Repository. For more information, please contact thinkir@louisville.edu. 


\title{
Whiteness in Du Bois's
}

\section{The Souls of Black Folk}

\section{David S. Owen}

\author{
Department of Philosophy \\ University of Louisville
}

W. E. B. Du Bois's work is often cited as an early precursor to the contemporary field of critical whiteness studies. Du Bois is famous in this regard for his claim in Black Reconstruction that despite being underpaid, white workers also received a "public and a psychological wage" for being white, and for his essay examining the "souls of white folk." Both writings are often referenced as evidence for Du Bois's interest in critically analyzing whiteness. ${ }^{1}$ The fundamental outlines of an analysis of whiteness, however, can be found in a close reading of his much earlier The Souls of Black Folk, and especially in the opening chapter, "Of Our Spiritual Strivings," wherein he introduces the key concepts of double consciousness and the Veil for understanding aspects of the black experience under conditions of white supremacy. ${ }^{2}$ In this paper I argue that in Souls Du Bois, at the same time he is expressly analyzing the experience of blackness, is also implicitly describing and analyzing whiteness. The consequence of indirectly uncovering and analyzing whiteness is to bring to the attention of his white readers the depth and pervasiveness of white supremacy in the Unired States. There are four aspects of Souls that I will focus on in developing this interpretation: (1) Du Bois's discussion in the opening paragraphs of blacks being "a problem"; (2) the concept of double-consciousness; (3) the figure of the Veil; and (4) the shaping of Souls for an audience of whites. I will argue that throughout this groundbreaking, interdisciplinary work Du Bois is implicitly describing the nature, structure, and significance of whiteness. Although Du Bois's stated intention is to describe the experience of blackness, he recognizes that a comprehensive examination requires attention to the conceptual other of whiteness, which because of its being normalized structures, shapes, and constrains the expression of blackness.

It should be noted, however, that my aim in reading the ways whiteness is encoded in Souls is not to re-center whiteness and whites in the original and important work of an African-American thinker. Rather, I seek to show that in Souls Du Bois had already identified whiteness as an important framework of analysis for the critique and dismantling of structures of white supremacy. I suggest that 
Du Bois understood the relational nature of blackness and whiteness and that interrogating one necessarily involves reflecting on the other. I argue that, as his analysis of double-consciousness shows, black identity is mediated through whiteness; it is fundamentally shaped by the racial order of white supremacy in which it is formed. And of course conversely, as other writers have shown, white identity is also formed by means of a mediation through blackness. ${ }^{3}$ Given his extensive study of the German philosophical tradition, it should not be surprising that Du Bois understood that in order to accurately depict the souls of black folk, he needed to also examine the nature and effects of whiteness. Because of their relational nature, he couldn't consider one without at the same time considering the other. Du Bois's radically re-framing of the understanding of race in America in terms of whiteness and its relationship to blackness thus does not re-center whites and whiteness-it is essential to adequately understanding and critiquing white supremacy. By destabilizing the hegemony of whiteness through exposing it as the unquestioned norm, Du Bois generates a new framework for the critique of white supremacy.

\section{On Being a Problem: Unmasking Whiteness}

In the opening paragraph of "Of Our Spiritual Strivings," Du Bois describes the experience of being perceived to be a problem:

Between me and the other world there is ever an unasked question: unasked by some through feelings of delicacy; by others through the difficulty of rightly framing it. All, nevertheless, flutter round it. They approach me in a half-hesitant sort of way, eye me curiously or compassionately, and then, instead of saying directly, How does it feel to be a problem? they say, I know an excellent colored man in my town; or, I fought at Mechanicsville; or, Do not these Southern outrages make your blood boil? At these I smile, or am interested, or reduce the boiling to a simmer, as the occasion may require. To the real question, How does it feel to be a problem? I answer seldom a word (Souls, 7).

The "other world" that asks this persistent question is not identified immediately, but since the author has already identified the subject of the work as "the strange meaning of being black here in the dawning of the Twentieth Century," the reference of the "other world" can hardly be anything but the world of whites (Souls, 3). Thus, Du Bois immediately opens Souls by identifying the background framework-a racial framework - that defines the horizons that delimit his descriptions and elaborations of the "meaning of being black." In light of this preexisting framing, asking this question of Du Bois from the perspective of the black experience would be senseless since, being black, one would either know what it felt like to be a problem-assuming the premise that one is a problem-or reject this very premise-that is, that one is a problem.

To be sure, this is a false dichotomy because the effects of internalized racism 
might result in blacks asking the same question. Since the intelligibility of the question presupposes a particular set of presuppositions about the social world, Du Bois is not merely marking the questioner's identity as white, he is in addition drawing attention to the perspective of the questioner as a white perspective, the meaning of which will be examined below. Moreover, since Du Bois has already announced his intention in the "The Forethought" of Souls to discuss "the problem of the color line," the "other world" that is set against him is undoubtedly the white world, which must be understood in terms of its perspective (Souls, 3). At the very outset, then, Du Bois announces, if indirectly, his intention to examine not only blackness, or what it means to be black, but also whiteness, and the meaning of this "other" term. Embedded within this brief paragraph, then, is the central claim that whites and blacks occupy two very different social realities and that understanding one requires understanding the other, as well as the relations between the two.

But is this all that this brief description of the question of what it is like to be a problem accomplishes? Does it merely announce indirectly the racially dyadic framing of the analyses to follow? Merely referencing the existence of two racialized social worlds that are at odds with each other (at least epistemically) would hardly be especially significant. In this paragraph, Du Bois is also addressing what might be called the problem of the black voice and the expression of the black experience, where the problem of the black voice is most fundamentally the problem of the lack of a black voice in the public sphere and dominant culture. Du Bois's framing of this question in terms of two distinct lifeworlds with different perspectives does the work of clearing a discursive space of expression and thereby opening up the possibility of articulating the black American experience from behind the Veil. In responding to the reviews of Souls a year after its publication, Du Bois stated that while readers may disagree with him, "at the same time some revelation of how the world looks to me cannot easily escape him [i.e., the reader]."4

It is clear, then, both from its title and from this statement that one of Du Bois's objectives in the publication of Souls was to describe the experience of being black in the U.S. in the late nineteenth century to the occupants on the other side of the color line, those living in the white lifeworld. But before such an experience can be expressed, a discursive space needs to be cleared; for without such a clearing, Du Bois's descriptions of the black experience would fall on the deaf ears of whites either as not credible-simply dismissed as the rantings of an angry black man, or an "uppity Negro" who doesn't know his place, or how good he's got it, or simply as incomprehensible. Du Bois accomplishes this clearing of a discursive space in which his descriptions of black experience can both be understood and taken seriously by whites by attempting to uncover and unmask the implicit presuppositions that shape the white sociocultural lifeworld. Once these presuppositions are called into question, something Du Bois does in an indirect manner, the legitimacy and credibility of an expression of the black experience is at least made possible for his white readership.

Du Bois underscores the norming of the presuppositions of whiteness in the dominant cultural worldview by describing the white world as that "other world." This is a quite significant, yet overlooked, trope. By othering the white world, 
Du Bois reverses the typical perspective on matters of race by shifting the point of view from the white to the black perspective, from dominant to marginalized worldview. This contrasts starkly with previous articulations of the black experience for white consumption in which authors such as Frederick Douglass and Booker T. Washington adopted what is called an "assimilationist" strategy in the sense that they sought to convince white readers that blacks had all of the cognitive, emotional, and spiritual experiences that whites do, and hence ought to be included in the (white) social world as full persons. Thus, in the dominant cultural discourse of the time (and of today), the Other would represent blacks and the self-same would represent whites, with the consequence that the perspective, interests, needs, and values of whites are normed. Du Bois, however, reverses this usual structure in order to create in his readers (and most especially in his white readers) a kind of cognitive dissonance, thus generating the necessary discursive space for the credible expression of the black experience.

Rather than answering the hovering question of how it feels to be a problem, Du Bois describes to his readers the experience and implications of always having this question as the background to any interactions across the color line. By taking this approach of not answering the question directly, he rejects the implicit assumption of the question: that blacks are the cause of, and responsible for, the problem of race. By redirecting the readers' attention to the experience of having the question always in the background, Du Bois draws attention to the normalized racial presuppositions that frame the question. Du Bois's language and structure here suggest that the problem is with being seen as a problem, that is, with the very conceptual framework presumed by the question. It is the character of exclusion determined by the perspective of whiteness that underlies this question that is the real problem, for the question presupposes a perspective of whiteness, and this perspective excludes and marginalizes the black experience. Thus, the problem is not of blacks, but one of whites, for it is they who reproduce and maintain the normalizing structures of whiteness that make such a question possible. ${ }^{5}$ It is because the dominant cultural understanding of race and racism is framed primarily by the white perspective that the persistence of racial injustice becomes a problem. By creating this shift and redirecting the focus of the question back onto the questioners (who are presumably white), he has drawn our attention to the existence and consequences of whiteness. Du Bois here is deploying the concept of "whiteness" without naming it, and his use of it suggests that he understands it to include the practice of taking the perspective of those racialized as white in our society as the norm. Du Bois is suggesting that it is only when framed by the norms of whiteness that such a question asked of blacks (i.e., "How does it feel to be a problem?") can possibly be meaningful. But then, once the normativity of whiteness is unmasked, the question's sense implodes. Once we see that the normativity of whiteness provides the grounds for the sense of the question, we also see that the question itself no longer makes sense, for it is not blacks that are the problem but the norming of whiteness itself that is. It is the presumption of the white perspective that is problematic, not the mere presence of blacks in a society structured by white supremacy. 


\section{Double Consciousness: Black Identity and Whiteness}

Even though in the first paragraph Du Bois exposes the presuppositions of whiteness that frame the question of being a problem, and as a result shears away its support so that the question is no longer coherent, in the second paragraph he does admit that "being a problem is a strange experience ..."(Souls, 7). Thus, we are introduced to the double perspective of his analysis: on the one hand, his analysis exposes the normative presuppositions of whiteness, and on the other hand, his analysis expresses the conflicted experience of being imprisoned in the marginalized, excluded, and subordinate position in a social order structured by white supremacy. By articulating the experience of subordination and exclusion, $\mathrm{Du}$ Bois gives voice to the racially marginalized and provides a critical perspective on the presuppositions of whiteness. But more importantly, Du Bois introduces the reader to the complexities of the experience of being racially oppressed. Du Bois first articulates these complexities by asking: "Why did God make me an outcast and a stranger in mine own house" (Souls, 8)? It is with this question that he first expresses the experience of double consciousness. This ever-present experience of double consciousness is a deeply conflicted soul, an experience he characterizes as a two-ness: "An American, a Negro; two souls, two thoughts, two unreconciled strivings; two warring ideals in one dark body, whose dogged strength alone keeps it from being torn asunder" (Souls, 8-9).

The passage that contains this description of double consciousness is in the first chapter of Souls, entitled "Of Our Spiritual Strivings," which is a revised version of an earlier essay, "The Strivings of the Negro People," published in Atlantic Monthly in 1897, which in turn is an evolutionary development of his famous talk to the American Negro Academy, "The Conservation of Races," in March of that same year. ${ }^{6}$ While more often the continuities between these different versions have been highlighted, Ernest Allen, Jr. argues that Du Bois's understanding of double consciousness changed substantially from "Conservation" to Souls. In the earlier essay, he argues that $\mathrm{Du}$ Bois had in mind an imaginary conflict between black and white ideals, while in the later work Du Bois had in mind by double consciousness a "negated black consciousness ... resulting from the failure to" reconcile "American and Negro existential ideals...." My interest here is only with the text of Souls, so I will not examine Allen's arguments concerning these two different senses of double consciousness, but I will return below to discuss his understanding of double consciousness as an "absence of true self-consciousness" (Allen, 52).

In contrast to Allen's interpretation, Thomas Holt stays closer to the typical understanding of this concept as a conflict between cultural ideals. On this orthodox interpretation of the concept of double consciousness, Du Bois captures the fundamental contradiction that lies at the heart of the American racialized social order. The contradiction lies between ideal and practice. On the one hand, American political ideals as enshrined in the Constitution ensure that all persons are afforded equal rights and privileges, yet on the other hand, because the social order governed by that constitution is racialized, those equal rights and privileges are vigorously defended for some while they are systematically denied to others (or as 
Du Bois might have put it-reversing the perspective of whiteness-they are vigorously defended for others and systematically denied to some). That this contradiction is ever present in the history of the Republic is not difficult to see, from the original justifications for chattel slavery, to the so-called Great Compromise of the Constitutional Convention of 1789 , Jim Crow laws, federally endorsed housing segregation, and the reversals of affirmative action policies in the past three decades. A society that is fundamentally structured by racism, as is the U.S., is in contradiction with the ideals that ostensibly serve as its founding principles. Thus, one aspect of the concept of double consciousness is the illumination of this fundamental contradiction in our social order.

But Du Bois is not merely bringing to his reader's attention the existence of this contradiction in our social order. Indeed, he is also expressing how this contradiction affects black identity. His phenomenological description of the experience of being a black American is one of being conflicted and torn between the so-called American ideals of freedom, equality, and individual dignity, which black Americans rightly presume should apply to them, and the black experience of being denied those ideals (sometimes in law, and sometimes in practice) by the order of white supremacy that pervades every aspect of our collective life. The experience that results is one of both fitting in and not fitting in, being welcome and unwelcome, being celebrated and hated. So even when the legal order formally permits the full inclusion of blacks into American society, black Americans will continue to feel (and be) alienated from that society because of a racialized culture that continues to sustain de facto white supremacy. The very celebration of Black History Month itself symbolizes the marginalization of blacks in so-called American culture, even though blacks have been integral to the development of that culture from its origins. This tension between being black and being "American" is always present and deeply affects the self-consciousness of black Americans.

The "twoness" of double consciousness is not merely a description of the experience of living in a racialized society, but it also points to how this racialized society structures and forms black identity. Du Bois analyzes the self-consciousness of black Americans as a meditated consciousness: it is a "sense of always looking at oneself through the eyes of others" (Souls, 8). The influence of Hegel on Du Bois's thought is clearly visible here. In The Phenomenology of Spirit Hegel famously argues that consciousness can only attain independent status as self-consciousness through the mediation of another consciousness. ${ }^{8}$ It is only through my consciousness being recognized by another consciousness that I attain a genuinely independent status as a self-consciousness, and what this means is that what I take to be true, the subjective truth that is tied to my perspective, is recognized as true by another consciousness. ${ }^{9}$ Since, according to Du Bois, the consciousness of black Americans is a self-consciousness that is generated "through the eyes of others," this analysis of black identity implies that it is dependent upon some other identity. And given his other remarks about double consciousness, it is clear that this other identity is white identity, which dominates the formation of the social order.

Ernest Allen, Jr., however, interprets Du Bois quite differently on this point. 
He argues that what Du Bois means by "double consciousness" is that blacks in fact lack genuine self-consciousness:

[W] hat Du Bois strictly meant by the phrase was the absence of true self-consciousness on the part of black Americans, the inability to recognize one's black self other than through the mediated veil of the unacknowledging white gaze. In this instance, Du Bois' frame of reference can be traced ultimately to Hegel's phenomenology, where true self-consciousness-supposedly lacking in the Negro-was dependent upon the mutual recognition of human beings by one another (Allen, 52). ${ }^{10}$

Allen's interpretation of Du Bois here is that true self-consciousness (i.e., the development of an independent identity) can arise only on the basis of mutual recognition. But the mutual recognition that results in the development of self-consciousness must be a mutual recognition between two equally-situated individuals. Since blacks are clearly not equally situated with respect to whites, being the victims of a system of white domination, they cannot in fact achieve true self-consciousness (within the context of such a social system). The result is that blacks do not achieve an independent identity. And, according to Allen, this is precisely what Du Bois means by "double consciousness" in Souls.

If this is a correct reading of Allen's argument, then he misreads Hegel and, consequently, Du Bois. Du Bois's grounding of black consciousness in mediation through white consciousness does not entail that blacks fail to achieve self-consciousness. There are two main stages in this part of Hegel's analysis of the development of consciousness: in the first, consciousness develops into self-consciousness, but only on the grounds of recognition by another consciousness; and in the second, self-consciousness achieves a genuinely objective point of view. When Du Bois is writing at the beginning of the twentieth century, the self-development of Hegelian "Spirit" has not yet achieved genuine self-consciousness with its objective point of view (and indeed the same can be said at the start of the twenty-first century), thus only the first stage of this analysis is applicable here. In the first stage, consciousness realizes that it must look beyond its own subjective determinations, that is, what counts as true for it, to another consciousness in order to have its (the first consciousness's) determinations validated as true. What ensues, then, is a struggle for recognition between two consciousnesses, with each demanding from the other recognition for its own determinations and also for its conception of itself as an independent consciousness: "Recognition can only come from an 'other' whom one takes to be a self-conscious agent (an agent who has a point of view on the world and therefore his own practical projects), and who confers that recognition on one. Each therefore makes a conflicting demand on the other" (Pinkard, 57). These conflicting demands are in fact contradictory demands; they cannot both be satisfied at this point since each demands recognition for the truth of her point of view exclusive of all others. Hegel understands this, then, as a life and death 
struggle, for it is about the existence of consciousness as an independently existing self-consciousness with a true point of view. But the victory of one consciousness and the death of the other will not solve the problem of recognition: "The struggle is ... not just over the satisfaction of desire but over what is to count as the objective point of view and thus what is to count as the truth" (Pinkard, 59). The consequence is that one of the consciousnesses accepts defeat rather than death and confers the demanded recognition on to the other. In this way, then, the conferral of recognition can occur, rather than the elimination of its possibility by the death of one of the consciousnesses.

At this point in the development of self-consciousness, the subjective point of view of one consciousness-in Hegel's terminology, the master-becomes dominant; its point of view is recognized and affirmed by the other consciousness-the slave-as determinative of truth. Thereby, the master's consciousness receives the recognition it needs in order to assure itself that its subjective point of view is in fact the objective point of view. On the other hand, the point of view of the slave's consciousness is now determined by the projects of the master. The field of both cognitive and affective values that it apprehends, which together direct its actions, is now shaped by the projects, interests, and needs of the master; in other words, the slave's point of view must now be integrated into the master's point of view and made consistent with it:

The slave ... understands that his desires count as good reasons to act only to the extent that their satisfaction can be integrated into a scheme of satisfying the master's desires ..., and he understands that the things of the world can count for him as values or as things to be appropriated by him only insofar as such valuings and appropriations can be integrated into the master's projects and desires (Pinkard, 60).

On Pinkard's reading of this relationship, the slave's point of view becomes subordinated to the master's point of view only on the condition that the slave-as a self-conscious agent-makes the choice to accept the master's point of view as determinative. To be sure, this is not an autonomous decision, but nonetheless, the recognition the master receives from the slave rests on the slave's conferral of that recognition.

What this means, then, is that "[t]he master's point of view thus proves to have no metaphysical or epistemological priority over the slave's point of view; its dominance turns out to be a social fact" (Pinkard 60). Once the master realizes the social contingency of the recognition she receives from the slave, she comes to see that her point of view has not been established as objective through its recognition by another consciousness. The contingently-grounded recognition that is conferred in this dialectic fails to establish the master's subjective point of view as objective and true, and the master comes to realize that the dominance of her point of view is in fact mediated by, and hence dependent upon, the slave. Correlatively, the slave, by apprehending that what he takes to be true (which is determined by the proj- 
ects of the master) is grounded in the social contingency of the dialectical relationship between them, comes to see that the dominance the master has over him (the slave) is also a result of contingent, because they are social, circumstances. Hence, both master and slave come to realize that their dominant and subordinate points of view are a consequence of a contingent state of affairs, and this undermines the point of the struggle for recognition: for self-consciousness to satisfy itself that its subjective point of view is objective and true. A result of this failure of self-consciousness to assure itself of the complete and true objectivity of its point of view, and hence of its own independence, both master and slave come to realize that each is dependent (though in different ways) upon the other.

But the dialectical development of the relation between master and slave does not end here. In the slave's coming to realize that he considers the master's point of view to be legitimate on merely contingent grounds, the slave also comes to realize that-for the same reasons-he in fact possesses a degree of independence. By supporting the projects of the master through working in the world, the slave realizes that those projects are only possible on the basis of the slave's labors, thus " $[t]$ o the extent that the slave comes to understand this- that he is a slave by contingency only and that his own activity is also constitutive of something's counting as a thing of value - he sheds the complete hold that the master had over his self-consciousness" (Pinkard, 62). ${ }^{11}$ In the end, then, (and this is not truly the end of the dialectic) the master and slave do not in fact find themselves in a simple relation of dominance and subordination. The master has not achieved complete independence and recognition of her point of view, and the slave is not fully dependent upon the master and does indeed possess a degree of independence himself. What this shows is that the original goal, full recognition and validation of one of the two points of view, cannot be achieved (at this stage). What is necessary, then, if the objective point of view and truth are still the goals, is to mutually construct a common point of view that can ground objectivity and truth. ${ }^{12}$ By means of this dialectic, each self-consciousness realizes that it must integrate the other into its own point of view: "What counts as his own projects for the master cannot be unambiguously identified without incorporating some reference to the slave's projects and visa versa" (Pinkard, 62). At this point, a kind of mutual recognition has been achieved where each self-consciousness sees the necessity of incorporating aspects of the other's point of view into its own, thereby laying the foundation of a genuinely intersubjective standpoint.

To be sure, a structure of domination and subordination continues to determine the relationship between the two self-consciousnesses. This is one reason why it cannot be said that a truly objective point of view has been achieved. Nonetheless, a certain degree of mutual recognition is unavoidable, entailing that each selfconsciousness is neither entirely independent of, nor completely dependent upon, the other. And so while the master/slave relation of domination/subordination remains, any degree of independence that each achieves is grounded at the same time on a relation of dependency upon the other.

Du Bois was thoroughly familiar with Hegel's Phenomenology of Spirit, and one can see the influences of the master/slave dialectic on his conception of dou- 
ble consciousness. ${ }^{13}$ For Du Bois, the double consciousness experienced by black Americans is the "sense of always looking at one's self through the eyes of others, of measuring one's soul by the tape and of a world that looks on in amused contempt and pity" (Souls, 8). Here we can clearly see the self-understanding of one self-consciousness as mediated through another self-consciousness. Black identity is mediated by white identity, that is, the ascriptive identity of blacks-how racial others see them-plays a significant role in the formation of black self-understanding. How the Other sees me shapes in central ways how I see myself.

Returning to Allen's interpretation of double consciousness as a description of "the absence of true self-consciousness on the part of black Americans, the inability to recognize one's black self other than through the mediated veil of the unacknowledging white gaze" (Allen, 52), I want to suggest that this is a misreading of both Hegel and Du Bois. On Hegel's analysis of the master/slave dialectic, the achievement of a stable self-consciousness is possible only on the grounds of a mediation of another consciousness. In other words, my self-consciousness is possible only insofar as it incorporates how another consciousness views me; this mutual recognition of two consciousnesses is necessary for the formation of self-consciousness. Thus, it is difficult to see how black consciousness, by unavoidably being mediated by white consciousness, fails to achieve true self-consciousness; on the Hegelian analysis, this is the only way self-consciousness is possible. Moreover, the Hegelian analysis also entails that white consciousness is mediated by black consciousness; that is, white identity is shaped in a significant manner by how blacks view them (See, e.g., Morrison).

To be sure, Allen is correct insofar as Du Bois does say that blacks are denied true self-consciousness: "the Negro is a sort of seventh son, born with a veil, and gifted with second-sight in this American world-a world which yields him no true self-consciousness, but only lets him see himself through the revelation of the other world" (Souls, 8). But I want to suggest that what Du Bois means here is that there is an asymmetry between the development of black and white self-consciousnesses, yet at the same time both self-consciousnesses are mediated through the other. A genuinely objective self-consciousness, according to Hegel, rests on the construction of a common, intersubjective point of view, and this necessarily rests on a certain degree of reciprocity. This degree of reciprocity, however, is lacking at this stage in history since there is a fundamental asymmetry in the socially structured relations between black and whites. In other words, the mediation of consciousness for black Americans is problematic precisely because the mediation itself is framed by a social system that is characterized by white supremacy. As Du Bois wants to show, it becomes problematic when one considers the development of self-consciousness within a social context structured by an asymmetrical hierarchy of race. The particular form of mediated consciousness that black Americans experience is structured by a hierarchical social order of domination and subordination. Mediated consciousness in this context is problematic because the subordinated consciousness is not recognized to be an independently existing agent by the dominating consciousness, and so it is: blacks have not been recognized as fully independent agents by the dominant American culture. (Yet, conversely, whites' 
self-consciousness also fails to achieve true independence.) Thus, black American identity is mediated through the consciousness of the Other, in this case whites. The consciousness of whites, or as Du Bois would articulate it, "white souls," is defined by "whiteness." What makes a consciousness a specifically white consciousness is that it is a racialized consciousness with a particular point of view. This point of view can be defined in terms of the interests, needs, and values of that consciousness. Du Bois's distinction between black and white consciousnesses, then, can be understood as drawing attention to the differently situated standpoints of each form of consciousness. Thus, in addition to elaborating black consciousness, Du Bois identifies whiteness as the essential meaning of white consciousness, as well as whiteness as the dominant term in the hierarchical structuring of the U.S. social formation.

How, then, does Du Bois understand the implications of this double consciousness for black identity? The nature of double consciousness, according to Du Bois, seems to require black Americans to choose one of their two identities: to either, following Frederick Douglass and Booker T. Washington, renounce their African heritage and assimilate into "Americanness," or, following Alexander Crummell, adopt an afrocentric stance by forgoing their Americanness and turning toward their African roots. But having to choose between these options is unsatisfactory for Du Bois, because it is a false dilemma: "[The black American] would not Africanize America, for America has too much to teach the world and Africa. He would not bleach his Negro soul in a flood of white Americanism, for he knows that Negro blood has a message for the world" (Souls, 9). The solution that Du Bois suggests is a pluralistic, multicultural America in which African-Americans can be both black and American, an America in which being American does not mean subscribing to the norms of whiteness. Thus, Du Bois is again offering an implicit critique of the hegemonic norming of white interests, needs, and values in the society and culture of the United States. The "twoness" of being both black and American is problematic only in a context of white supremacy; dismantling white supremacy does not rid us of the categories "black" and "American," or of their cultural content, but what then becomes possible is a sociocultural pluralism that does not embody the norms of whiteness as dominant.

I argue that, in effect, what the concept of double consciousness describes is the consequence of the conflict-a struggle for recognition-between whiteness and blackness. In a racialized social order, this conflict is not one of equals but a conflict between the dominant and the subordinate, thus it is a conflict that is hierarchical and asymmetrical. The sociocultural norming of whiteness takes the interests, needs, and values of whites as the standard and all other interests, needs, and values as deviant from the norm. These interests, needs, and values of whites are the distillate of a contingent history-just as in the master/slave dialectic, both master and slave come to realize that the recognition they receive from the other is only contingently motivated-and they are maintained by social practices, thus this is not an essentializing description of whites. Normalizing the point of view or standpoint of whites constitutes an immense degree of power, for the effects of normalization remain largely unrecognized by the dominant culture. As has been discussed 
extensively in the literature on whiteness, the normalization of whiteness is largely a transparent phenomenon. That is, whites typically are not conscious of how their own perspective has been normalized and that this normalization generates a set of racial privileges of which they remain unaware. What is especially noteworthy here is that the relation between whiteness and blackness becomes a problematic conflict only when they are situated hierarchically in relation to each other.

Du Bois not only theorized and described the development of black self-consciousness (and concomitantly, whiteness), but he also engaged in interventions in this developmental process, of which his editorship of The Crisis is a prime example. There is another intervention of his that illustrates both the concept of double consciousness and the dialectical development of self-consciousness. In 1900, Du Bois assembled a series of photographs to be exhibited at the "American Negro" exhibit of the Paris Exposition. ${ }^{14}$ As Shawn Michelle Smith argues, $\mathrm{Du}$ Bois used this collection of photographs to "disrupt the images of African Americans produced 'through the eyes of others' by simultaneously reproducing and supplanting these images with a different vision of the 'American Negro'" (Smith, 581). These images were presented as contemporary portraits of African Americans, but their style, format, and the subjects' poses suggested criminal mug shots: "when projected trough the eyes of white others, the image of the African American middle-class individual often transmuted into the mug shot of an African American criminal" (Smith, 585). Smith's argument is that with these photographs, Du Bois unmasks and challenges the normalizing gaze of whiteness that shapes African American identity formation. In Hegelian terms, Du Bois's Paris Exhibition photographs challenge the dominant (master) self-consciousness as an independent consciousness, for they "trouble" the self-assurance of the dominant consciousness: "The photographs begin to disrupt the authority of the white observers by collapsing the distance between viewers and objects under view that is held traditionally to empower observers" (Smith, 587). Moreover, in the Paris Exhibition photographs, Du Bois expresses the self-understanding of blacks that they are not entirely dependent upon the dominant consciousness (i.e., whiteness). Thereby the dialectical development of white and black self-consciousness arrives at the stage of the necessity of mutual recognition. Thus, in the same period as the writing of Souls, Du Bois can be seen enacting the Hegelian dialectical development of selfconsciousness. Smith's understanding of the significance of the Paris Exposition photographs reinforces the argument that in Souls Du Bois is presupposing and hinting at an understanding of whiteness as a sociostructural pattern of domination that shapes both white and black consciousness.

Finally, it is worth noting that the social situation of white supremacy that Du Bois sees as the ground for double consciousness is structured analogously to the proletariat/bourgeois structure described by Marx..$^{15}$ What is relevant about this structure, in which one term identifies the socially dominant group and the other term identifies the dominated or oppressed group, is that for Marx as well as later Marxist theorists the oppressed group (the proletariat in his case) possessed a unique insight into the true operations of the social order, whereas the dominating group tends to be blinded to certain truths about their social situation. ${ }^{16}$ Thus, 
the fact of double-consciousness does not refer merely to the structuring of black identity, but also to the capacity of blacks to understand the true nature of the social formation. In Thomas Holt's analysis of the alienation of blacks in Du Bois's work during this period, this alienation should be celebrated for the reason that since "they live in two worlds at once, African-Americans possess the power to see where others are blind" (Holt, 306). The value of the alienation generated by double consciousness is also recognized in Ernest Allen, Jr.'s interpretation of Du Bois's reference to blacks' "second sight." Allen argues that "Du Bois may have implied by [second sight] 'an expanded consciousness allowing one that ability to navigate two disparate cultures fluently ... or from the perspective of one's own culture, the skill to perceive in another that which is opaque to its practitioners.' "17 Here, Allen seems to clearly share my reading of at least the implications of the second sight of double consciousness, although Allen's interpretation rests on distinguishing Du Bois's uses of "double consciousness," "twoness," and "second sight" in a way that I do not. Nonetheless, the point here is that the concept of double consciousness is not merely one of situating two different perspectives, standpoints, or worldviews in relation to one another, but that the these two "worlds" are hierarchically situated with respect to one another in their shared social formation; a consequence of this is that the lower term in the hierarchy, the dominated or oppressed group, possesses a truer understanding of the operations of the social order than does the higher term in the hierarchy, the dominating or dominant group.

\section{The Veil between Blackness and Whiteness}

Throughout Souls Du Bois describes black Americans as living behind what he calls a Veil. Part of the work that the figure of the Veil does is to describe the marginalizaton of blacks in American society and culture, that is, how there is a barrier or gap between black and white experience. For example, Du Bois discusses in Souls his encountering the Veil as a school teacher in rural Tennessee. When he interviews for his first posting he describes how the "shadow of the Veil" falls when he eats dinner at the home of the white school commissioner and his wife (Souls, 51). Although in words he is treated respectfully and invited to stay for dinner, he is required to eat after the commissioner and his wife, and alone. Here, Du Bois is marginalized by the practices of the whites he encounters because of his racialized blackness, even though he is at the same time treated with the respect due a highly qualified teacher. The respect he receives because of his status as a teacher is a hollow form of respect, a respect in form only. Its hollowness derives from its being constrained and limited jointly by the facts of his blackness and the sociocultural structures of whiteness. These two facts jointly prohibit the bestowing of a substantively meaningful respect. Consequently, Du Bois understands this incident as an example of how the Veil hangs between blacks and opportunity, despite their best efforts at self-improvement (Souls, 54). The figure of the Veil describes the invisible barrier-whiteness-between blacks and whites in this white supremacist culture and, further, how this barrier is a substantive barrier to meaningful equality.

$\mathrm{Du}$ Bois also uses this figure in contexts where he wants to emphasize that 
blacks are not similarly situated as whites with respect to the dominant culture, that there is an asymmetry in the structure of mutual recognition. Understood in this way, the Veil draws attention to the asymmetrical positioning of blackness to whiteness, of black self-consciousness to white self-consciousness. In common usage, a veil is something that is intended to be placed over something that should be covered. In marriage ceremonies and Muslim culture, veils are used to hide women's faces in public. In this sense, veils are used to cover something that should remain hidden. Veils are placed (or worn) intentionally, and they place something out of sight when in a public space. Understood in this way, then, the Veil that Du Bois speaks of is intentionally placed and used to hide something that should not be seen in public. The Veil is an effect of the history of white supremacy in the U.S., which is a consequence of the history of enslavement, exploitation, and oppression of blacks for material and psychological gain. In his choice of the metaphor of the Veil, Du Bois suggests that the oppressive structures that continue to inhibit equitable opportunities for blacks have been willfully constructed and are intentionally maintained. Furthermore, the Veil that covers blacks is intended to make them (blacks) invisible to the public, where the public is characteristically a white public. As Ralph Ellison has so eloquently described, being black in America is the experience of being invisible. ${ }^{18}$ By functioning to cover, marginalize, and make invisible blacks and black consciousness, the Veil is whiteness, where whiteness defines the racialized norms of what can and should be seen. As a metaphor for whiteness, the Veil places out of sight to the dominant culture the lives and experiences of blacks. In other words, the interests, needs, and values of blacks are enshrouded and removed from public notice, consideration, and valuing. Note that $\mathrm{Du}$ Bois utilizes the trope of the Veil to draw attention to whiteness because he cannot name whiteness directly. For if he were to name whiteness, his white readership (see below) would fail to see this whiteness because of the psycho-social mechanisms that operate to defend one's position and status in the world. ${ }^{19}$

Moreover, veils can have positive, constructive aspects. ${ }^{20}$ They can clear a space for the construction of alternative identities-especially identities that are non-ascriptive and resistant-and they can form sites for subversion of the dominant order. Du Bois seems to allude to this aspect in his metaphor of the Veil as well. When describing the nature of the book in "The Forethought," he says, "[1]eaving, then the world of the white man, I have stepped within the Veil, raising it that you may view faintly its deeper recesses,-the meaning of its religion, the passion of its human sorrow, and the struggle of its greater souls" (Souls, 3). Here we see Du Bois highlighting the piety, virtues, strengths, and creativity of black folk, something he returns to repeatedly throughout his career, especially in The Gift of Black Folk. ${ }^{21}$ His purpose is not simply to uncover for his white readers the suffering of blacks caused by the system of white supremacy, but at least as importantly to make visible and immediate to his white readers the humanity of blacks. In particular, he wants to show that blacks possess the specifically human characteristic of moral agency that is denied by the ideology of white supremacy.

But the Veil does more than enshroud the "souls of black folk" from the view of whites. By doing so, it also functions to inhibit an awareness by whites of the 
implicit norming of whiteness. When black souls are out of sight and are not considered part of the social sphere, then the perspective of whites becomes the only apparent perspective available for whites. This masks the norming of the perspective itself; whiteness itself becomes invisible. Although this invisibility is a central property cited by contemporary theorists of whiteness, there is some disagreement about it. Barbara Flagg, for example, has argued that this "transparency" of whiteness is one of its essential properties. ${ }^{22}$ Ruth Frankenberg, however, argues that whiteness is eminently visible since it fundamentally structures the social and cultural worlds. ${ }^{23}$ What I suggest is that what are visible are indeed the norms of whiteness, but what remains invisible is the very fact that these norms are norms of whiteness. Thus, it is the content of whiteness that is visible and the functioning of whiteness within the social order that remains invisible (to whites). In his example, Du Bois's hosts understood they were marginalizing him and his interests, but they did not understand that their actions normalized themselves and their own interests, thus supporting a white supremacist social order. Because of the operations of whiteness and its generation of epistemic norms (among others), his hosts did not understand and recognize the whiteness in their presuppositions. Their behavior was "normal" for whites, and thus went (largely) unquestioned and unexamined. Thus, it is the content of whiteness (the norms themselves) that is visible and the function and operations of whiteness within the social order that remain invisible (especially to whites).

Thus, it is my claim that in Souls Du Bois implicitly understood whiteness and how it functions to maintain a social system infected with white supremacy. The metaphor of the Veil perhaps comes closest to naming whiteness for what it is; the Veil is whiteness, at least it has the same functional role in the social order as does whiteness.

\section{Du Bois's White Readers}

In examining the evolution of Du Bois's ideas from "The Conservation of Races" (1897) through "The Strivings of the Negro People" (1897) to "Of Our Spiritual Strivings" (1903), Thomas Holt notes that "Conservation" was "addressed to a black audience; indeed, it is an exhortation to the 'talented tenth' for selfappointed racial leadership," while the opening essay of Souls was addressed "primarily to a white audience" (Holt, 303). Yet Holt must presume the self-evident nature of this second claim since he does not provide either textual or contextual evidence for it. Regardless of its obviousness, I suggest that the conceptual content of Souls implies that the primary function of the work is to inform, and to raise the consciousness of, whites concerning the nature of whiteness and its structuring of the social order. To be sure, Du Bois achieves this indirectly through discussions of the meaning of being a "problem," the concept of double consciousness, and the metaphor of the Veil.

By describing the marginalization of the black experience as being veiled, Du Bois makes visible one of the central mechanisms by which racial inequality is maintained in social practices, in institutions, and in cultural representations. But 
in Souls Du Bois means to go beyond merely describing this mechanism of racial oppression. The explicit purpose of the work is to sketch the depth and complexity of the souls that live behind the Veil. By doing this, he provides a picture of what lies behind the Veil, thus rendering the veiling ineffective. If this is a correct depiction of Du Bois's intentions, then the implication is that Du Bois was writing Souls primarily for a white readership (or, more precisely, for a readership that had internalized whiteness, whatever their racialized identity).

In Souls he makes public precisely what the Veil is intended to keep from public view. In practice, this means describing the various aspects of blackness in contrast to the dominant figure of whiteness and making blackness visible to whites. In this way, Du Bois disrupts the power of whiteness to evade the question of the humanity of blacks by expressing what typically remains unspoken. Whiteness functions by means of a hegemonic domination of the social and cultural world, and by definition this hegemony marginalizes the very existence of blackness. By articulating the experience of blackness, Du Bois finds a way to undercut the hegemonic power of whiteness. The depiction of black experience for a white audience disrupts the comprehensiveness and normalcy of the white perspective. Once whiteness loses its hegemonic grip on social practices and institutions and cultural representations, its ability to reproduce itself is problematized.

But merely articulating the experience of an Other will not necessarily disrupt the structures that maintain the asymmetrical relations between self and other. Du Bois's text recognizes this and seeks to point to-if indirectly-the existence and operations of whiteness that function to reproduce and maintain the asymmetrical relations between whites and blacks. The significance of Souls, then, is not so much in its original depiction of blackness, but in its unveiling before a white readership of the norming of presuppositions of whiteness. Making such taken-for-granted norms visible undercuts their effectiveness, for whiteness functions so effectively at maintaining the white supremacist social order precisely because its norming of the interests, needs, and values of whites is transparent to whites. Thus, embedded in the text are hints, suggestions, images, indirect references, associations, and so on that direct the reader's attention to the existence of a sociocultural whiteness and how it functions to maintain a racially unjust social order. Without directly identifying the hegemony of whiteness as his target, Du Bois finds a way in Souls to explain how whiteness functions and thereby to undermine its effectiveness.

\section{Conclusions}

I have argued that, despite its express focus on the black experience, in Souls Du Bois is also unmasking, analyzing, and critiquing sociostructural whiteness. If I am correct, then Du Bois was developing an understanding of whiteness even earlier than in his more famous references to it in Black Reconstruction and "The Souls of White Folk." His analysis of the problem of the color line in America is unique in a variety of ways, but it is most constructive in its re-articulation of the perspective from which race is understood. The supreme value of Souls is found in its identification and disruption of the presuppositions that define the sociocultural 
location whiteness. His analysis and critique of whiteness remains relevant today because the persistence of racial injustice in the face of a public ideology of inclusiveness and equality requires explanation, and I would argue that understanding the norming of the presuppositions of whiteness can provide the necessary explanation. Du Bois insightfully sees that racial injustices rest in fundamental ways on unarticulated and often unconscious presuppositions that underlie and frame sociocultural norms.

The lessons taught by Du Bois here are lessons that in many ways we still have not learned. In many respects, the problem of racial injustice is still seen to be a problem of people of color or of blackness, and not a problem that centrally involves whites and whiteness. Thinking of the problem of race as one that concerns only people of color presumes a normed perspective of whiteness, and understanding this is crucial to developing a deeper and more effective analysis of sociocultural racialization processes. Moreover, understanding that the black experience is complicated by a double consciousness is important for decentering the norms of whiteness. When whiteness functions as the unarticulated and unacknowledged norm, groups that possess differing interests, needs, and values will be marginalized in invisible ways (though often invisible only to the dominant group). The persistence of broad and deep racial inequalities can best be explained, I would argue, by the normative functions of whiteness in our social practices, institutions, and cultural representations. The effect of the norming of whiteness is the marginalization of blackness. The contributing causes of this marginalization will not be identified (and hence disrupted) unless whiteness itself is acknowledged and analyzed. Finally, seeing how whiteness functions as a set of norms that structure social and cultural life is necessary if we are to make visible those that are structurally rendered invisible. Not only pointing out the existence of the Veil, but also lifting and eliminating it, is essential if the racially marginalized and excluded are to exercise an effective voice in their own self-determination. Whites continue to be largely unconscious of their racial privileges, which are exhibited in all aspects of the modern social world. The fact that public discussions of the very existence of white privilege continue to be very controversial and divisive is evidence that the normativity of whiteness remains unacknowledged and powerfully hegemonic. Du Bois's contribution is to begin the lifting of the Veil and to give a voice to those who exist under its shadow so that the Veil itself can be challenged and deconstructed. This remains necessary insofar as black Americans, as well as other Americans of color, continue to be rendered largely invisible and marginalized by the whiteness that colors the social order. In these ways, Du Bois has provided us in The Souls of Black Folk with an early, yet still relevant to us today, glimpse of the nature and functioning of whiteness.

\section{Acknowledgments}

I would like to thank David L. Mosley for organizing and inviting me to participate on a panel discussion commemorating the centennial of the publication of Souls of Black Folk that first prompted me to think of how Du Bois analyzes whiteness. I am also grateful for helpful comments from Milton F. Brown, David L. 
Mosley, Avery Kolers, Falguni A. Sheth, Sherri Wallace, and the participants in the 2004 California Roundtable on the Philosophy of Race meeting held at the University of San Francisco.

\section{Works Cited}

Alcoff, Linda, and Potter, Elizabeth, eds. Feminist Epistemologies. New York: Routledge, 1993.

Allen, Jr., Ernest. "On the Reading of Riddles: Rethinking Du Boisian 'Double Consciousness'." In Gordon, Lewis R., ed. Existence in Black: An Anthology of Black Existential Philosophy. New York: Routledge, 1997.

Du Bois, W. E. B. Black Reconstruction in America, 1860-1880. Oxford: Oxford University Press, 2007.

Du Bois, W. E. B. The Gift of Black Folk: The Negroes in the Making of America. New York: Washington Square Press, 1970. (Originally published 1924.)

Du Bois, W. E. B. The Souls of Black Folk. New York: Vintage, 1990.

Du Bois, W. E. B. "The Souls of White Folk," in Darkwater. New York: Washington Square Press, 2004, 21-37.

Ellison, Ralph. Invisible Man. New York: Vintage, 1995.

Flagg, Barbara J. " 'Was Blind, But Now I See': White Race Consciousness and the Requirement of Discriminatory Intent." Michigan Law Review 91. 1993.

Frankenberg, Ruth. “The Mirage of an Unmarked Whiteness." In Rasmussen, Birgit Brander, Klinenberg, Eric, Nexica, Irene J., and Wray, Matt, eds. The Making and Unmaking of Whiteness. Durham: Duke University Press, 2001.

Hegel, G. W. F. The Phenomenology of Spirit. Section B.IV.A: "Independence and Dependence of Self-consciousness: Lordship and Bondage." Miller, A. V., tr. Oxford: Oxford University Press, 1977.

Holt, Thomas C. "The Political Uses of Alienation: W. E. B. Du Bois on Politics, Race, and Culture, 1903-1940." American Quarterly 42:2. 1990.

Lewis, David Levering. W. E. B. Du Bois: Biography of a Race, 1868-1919. New York: Henry Holt, 1993.

Lukács, Georg. "Reification and the Consciousness of the Proletariat." In History and Class Consciousness, Rodney Livingstone, tr. Cambridge, Mass.: The MIT Press, 1971.

Marx, Karl and Engels, Friedrich. The Communist Manifesto. Moore, Samuel, tr. Middlesex: Penguin, 1967.

Morrison, Toni. Playing in the Dark: Whiteness and the Literary Imagination. New York: Vintage, 1992.

Pinkard, Terry. Hegel's Phenomenology: The Sociality of Reason. Cambridge: Cambridge University Press, 1994.

Smith, Shawn Michelle. "'Looking at One's Self Through the Eyes of Others': W. E. B. Du Bois's Photographs for the 1900 Paris Exposition." African American Review. Vol. 34. No. 4. 2000. 
Sullivan, Shannon. Revealing Whiteness: The Unconscious Habits of White Privilege. Bloomington: Indiana University Press, 2006.

Yancy, George. "W. E. B. Du Bois on Whiteness and the Pathology of Black Double Consciousness." American Philosophical Association Newsletters: Philosophy and the Black Experience, Vol. 4. No. 1 (Fall 2004): 9-22.

Zamir, Shamoon. Dark Voices: W. E. B. Du Bois and American Thought, 1888-1903. Chicago: University of Chicago, 1995.

\section{Notes}

1. W. E. B. Du Bois, Black Reconstruction in America, 1860-1880 (Oxford: Oxford University Press, 2007), 573; "The Souls of White Folk," in Darkwater (New York: Washington Square Press, 2004), 21-37. Also see George Yancy, "W. E. B. Du Bois on Whiteness and the Pathology of Black Double Consciousness," American Philosophical Association Newsletters: Philosophy and the Black Experience, Vol. 4, No. 1 (Fall 2004): 9-22.

2. W. E. B. Du Bois, The Souls of Black Folk (New York: Vintage, 1990). Henceforth cited as Souls.

3. See, e.g., Toni Morrison, Playing in the Dark: Whiteness and the Literary Imagination (New York: Vintage, 1992). Henceforth cited as Morrison.

4. W. E. B. Du Bois, "Response," The Independent 57 (1904): 1152.

5. Keith Byerman also interprets Du Bois's text as implying that whites, not blacks, are the problem, though he understands this as grounded in the uncertainty about white identity and status that the text generates. "W. E. B. Du Bois and the Construction of Whiteness," in The Souls of Black Folk: One Hundred Years Later, ed. Dolan Hubbard (Columbia: University of Missouri Press, 2003).

6. Thomas C. Holt, "The Political Uses of Alienation: W. E. B. Du Bois on Politics, Race, and Culture, 1903-1940," American Quarterly 42:2 (1990): 301-21. Henceforth cited as Holt.

7. Ernest Allen, Jr., "On the Reading of Riddles: Rethinking Du Boisian 'Double Consciousness'," in Existence in Black: An Anthology of Black Existential Philosophy, ed. Lewis R. Gordon (New York: Routledge, 1997), 50. Henceforth cited as Allen.

8. See G. W. F. Hegel, The Phenomenology of Spirit, tr. A. V. Miller (Oxford: Oxford University Press, 1977), Section B.IV.A: "Independence and Dependence of Self-consciousness: Lordship and Bondage," 111-19.

9. Terry Pinkard, Hegel's Phenomenology: The Sociality of Reason (Cambridge: Cambridge University Press, 1994), 55-59. My understanding of Hegel throughout follows Pinkard's clear and compelling interpretation in Hegel's Phenomenology. Henceforth cited as Pinkard.

10. Allen cites S. Adell, Double Consciousness/Double Blind: Theoretical Issues in TwentiethCentury Black Literature (Urbana: University of Illinois Press, 1994).

11. Pinkard understands one of the consequences of this to be that the slave has come closer to achieving what the master could not: the construction of a "social, quasiobjective point of view out of his subjective point of view through his encounter with the other" (62). It should be noted that, given the correctness of this interpretation, this is the original formulation of a privileged standpoint epistemology. 
12. Note that the grounding of objectivity and truth is an essential part of the project of the Phenomenology and the master/slave dialectic is only a part of this grander narrative.

13. David Levering Lewis, W. E. B. Du Bois: Biography of a Race, 1868-1919 (New York: Henry Holt, 1993), 139-40; Shamoon Zamir, Dark Voices: W. E. B. Du Bois and American Thought, 1888-1903 (Chicago: University of Chicago, 1995), Chs. 4 and 6.

14. Shawn Michelle Smith, "Looking at One's Self Through the Eyes of Others': W. E. B. Du Bois's Photographs for the 1900 Paris Exposition," African American Review Vol. 34, No. 4 (2000): 581-99. Henceforth cited as Smith.

15. Karl Marx and Friedrich Engels, The Communist Manifesto, tr. Samuel Moore (Middlesex: Penguin, 1967).

16. Karl Marx, Eighteenth Brumaire of Louis Bonaparte (New York: International Publishers, 1964); and Georg Lukács, "Reification and the Consciousness of the Proletariat," in History and Class Consciousness, tr. Rodney Livingstone (Cambridge, Mass.: The MIT Press, 1971). This insight has been further developed by recent feminist theorists: see eds. Linda Alcoff and Elizabeth Potter, Feminist Epistemologies (New York: Routledge, 1993).

17. Allen, "On the Reading of Riddles," cited at note 7, above, 66, n. 2 (quoting Ernest Allen, Jr., "Ever Feeling One's Twoness: 'Double Ideals' and 'Double Consciousness' in The Souls of Black Folk," Contributions in Black Studies 9/10 (1992): 55-69).

18. Ralph Ellison, Invisible Man (New York: Vintage, 1995).

19. For an insightful and illuminating examination of how "habits of whiteness" can be actively resistant to change, see Shannon Sullivan, Revealing Whiteness: The Unconscious Habits of White Privilege (Bloomington: Indiana University Press, 2006).

20. I would like to thank Falguni A. Sheth for pointing this out to me.

21. The Gift of Black Folk: The Negroes in the Making of America (New York: Washington Square Press, 1970 (originally published 1924)).

22. Barbara J. Flagg, "Was Blind, But Now I See': White Race Consciousness and the Requirement of Discriminatory Intent," Michigan Law Review 91 (1993): 953.

23. Ruth Frankenberg, "The Mirage of an Unmarked Whiteness," in eds. Birgit Brander Rasmussen, Eric Klinenberg, Irene J. Nexica, and Matt Wray, The Making and Unmaking of Whiteness (Durham: Duke University Press, 2001), 72-96. 